Renata Raszka

https://doi.org/10.26881/pwe.2020.50.10

ORCID: 0000-0002-3318-0699

Uniwersytet Śląski

renata.raszka@us.edu.pl

\title{
Dziecko w środowisku pieniądza: \\ przekonania podzielane przez dzieci w wieku 8-9 lat
}

\section{Summary}

\section{A child in the money environment: beliefs shared by eight- and nine-year-old children}

This article is a report from qualitative research conducted by the text's author. Third grade primary school pupils who took part in the study have expressed their view of money by completing twelve incomplete sentences about money. The aim of the study was to find children's shared beliefs about money. In accordance with the instrumental and symbolic nature of money there appear to be two main groups of phrases ending incomplete sentences. Some of children's statements refer to instrumental understanding of money, that is, they relate to its value in use and economic functions. Other statements are connected with the symbolic nature of money, showing its psychological and social functions.

Keywords: dualistic nature of money, „the concept of money”, colloquial knowledge, third grade primary school pupils

Słowa kluczowe: dualistyczny charakter pieniądza, pojęcie ,pieniądz”, wiedza potoczna, uczniowie III klasy szkoły podstawowej

\section{Wprowadzenie}

Pieniądz nie należy do łatwych przedmiotów rozważań naukowych. Jeden z dylematów dotyczy genezy pieniądza. W literaturze przedmiotu przyjmuje się dwie główne koncepcje (hipotezy) dotyczące tej kwestii: antropologiczną (z dwiema odmianami: religijną i społeczną) oraz ekonomiczną. Obie koncepcje odnoszą się do wymiany, ale w pierwszej można mówić o wymianie posążek za plony (antropologiczno-religijna) lub prezenty za akceptację społeczną (antropologiczno-społeczna), a w drugiej - pieniądze za dobra i usługi. Pierwsza hipoteza wiąże się z uznaniem, że potencjalnie pieniądze nie są jedynie elementem wymiany ekonomicznej, lecz mogą także służyć zaspokajaniu innych potrzeb. W koncepcji ekonomicznej fakt ten jest raczej ignorowany (Wąsowicz-Kiryło 2008: 23-25; Gąsiorowska 2014: 15-18). Drugi dylemat obecny w opracowaniach naukowych na temat pieniądza wiąże się z próbą odpowiedzi na pytanie: co jest lub może być pieniędzmi, jakie pełni on funkcje. Upraszczając, przyjmuje się, że każdy przedmiot może 
być pieniądzem, jeśli spełnia następujące warunki: jest łatwy do standaryzacji (tak, aby szybko można było ocenić jego wartość), szeroko akceptowany i rozpoznawany, podzielny (można go rozmieniać), odporny na zniszczenie, nie sprawia trudności z noszeniem i utrzymuje swoją wartość w czasie (Furnham, Argyle 2000; Mishkin 2002; Wąsowicz-Kiryło 2008: 23-25, 29; Gąsiorowska 2014: 15-18).

Rozważania na temat pieniądza utrudnia ponadto dwoistość jego natury: instrumentalna i symboliczna (Belk, Wallendorf 1990: 35-67; Lea, Webley 2006: 161-209; Wąsowicz-Kiryło 2008: 33-36; Gąsiorowska 2013: 471, 2014: 10, 18-26). Rozróżnienie między instrumentalnym a psychologicznym znaczeniem pieniędzy można dostrzec nie tylko w badaniach, ale i w warstwie językowej. Agata Gąsiorowska używa słowa "pieniądz" (w liczbie pojedynczej) w celu zaakcentowania instrumentalnego rozumienia pieniądza, liczbą mnogą posługuje się natomiast wtedy, gdy pisze o psychologicznym znaczeniu pieniędzy i ich symbolicznej naturze (Gąsiorowska 2014: 10-11). W celu wskazania instrumentalnego rozumienia pieniądza i podkreślenia jego jednorodności, jednolitości, uniwersalności i zamienności będę używała słowa „pieniądz” w liczbie pojedynczej. Natomiast liczbę mnogą będę stosować w odniesieniu do psychologicznego znaczenia pieniędzy i ich symbolicznej natury, zwracając tym samym uwagę na wielość znaczeń, funkcji psychologicznych, form, źródeł pochodzenia i sposobów wykorzystania tego zasobu.

Rozważania dotyczące pieniądza podejmowane w obrębie ekonomii koncentrują się na jego funkcjonalnych aspektach i traktowaniu go przede wszystkim jako środka wymiany. Psychologiczne podejście do pieniądza oznacza natomiast koncentrację na przypisywanych mu subiektywnych znaczeniach oraz psychologicznych i społecznych funkcjach, jakie pełni w życiu człowieka. Odróżnia się ono od podejścia ekonomicznego również tym, że nie ignoruje się w nim faktu, że ludzie mają zróżnicowane podejście do pieniędzy, motywów leżących u podłoża decyzji finansowych czy też wagi, jaką przypisują zachowaniom finansowym i ich konsekwencjom. Taka postawa komplikuje jednak prowadzenie analiz dotyczących pieniądza (Wąsowicz-Kiryło 2008: 37). Joanna Rutkowiak (2012: 27), rozważając relacje między pieniądzem i wychowaniem, podkreśla, że pieniądz jako fenomen ekonomiczny rzadko występuje w tekstach pedagogicznych. Autorka zauważa ponadto, że obecne komplikacje „spieniężonego” świata stanowią wyzwanie dla pedagogów. Sytuacja ta może stać się punktem wyjścia do pracy wychowawczej, np. do inicjowania rozmów prowadzonych przez wychowawcę z wychowankami (Rutkowiak 2012: 38).

Przyjęcie antropologicznej perspektywy w odniesieniu do pochodzenia pieniędzy (co powoduje, że na pierwszym miejscu stawia się ich znaczenie psychologiczne czy społeczne, a nie tylko wartość użytkową i funkcje ekonomiczne) koreluje z wynikami badań przeprowadzonych z małymi dziećmi w wieku przedszkolnym (Gąsiorowska i in. 2012). Rezultaty tych badań wskazują na duże prawdopodobieństwo, że socjalizacja w zakresie reagowania na symboliczną naturę pieniędzy rozpoczyna się wcześniej i ma wpływ na tempo i sposób przebiegu socjalizacji w zakresie poznawania instrumentalnej natury pieniądza.

Tomasz Zaleśkiewicz, odwołując się do prowadzonych współcześnie badań, podkreśla, że: „interpretowanie pieniądza jako środka wymiany, dla którego charakterystyczne 
są wyłącznie instrumentalne funkcje ekonomiczne, jest sporym uproszczeniem. Pieniądz wydaje się mieć także naturę symboliczną i emocjonalną, przez co wpływa regulacyjnie na zachowania społeczne oraz uczucia doznawane przez człowieka. Działanie w kontekstach związanych z pieniędzmi wywołuje poszukiwanie większej niezależności od innych, ale jednocześnie osłabia działanie lęków egzystencjalnych. Wyniki badań eksperymentalnych sugerują nawet, że pieniądze mogą dawać człowiekowi symboliczne poczucie nieśmiertelności. Co więcej, ekspozycja bodźców związanych z pieniędzmi wpływa na preferencje i zachowania małych dzieci, które dysponują stosunkowo niewielką wiedzą o świecie ekonomii i słabo radzą sobie z wykorzystywaniem pieniędzy w praktycznych sytuacjach (np. popełniają liczne błędy w ocenie nabywczej wartości pieniądza). Może być zatem tak, że specyficzne reagowanie na symboliczną naturę pieniądza rozwija się szybciej niż rozumienie jego funkcji ekonomicznych" (2012: 119-120).

\section{Potoczna (zdroworozsądkowa) wiedza jako źródło i efekt rozumienia rzeczywistości}

Wiedza osobista określana jest również jako wiedza ukryta, milcząca, proceduralna, operacyjna, potoczna, wiedza w działaniu, wiedza, która wiąże się z naturalnym, spontanicznym doświadczeniem rzeczywistości itd. (Kochanowska 2018: 12-13, 15). Dzieci nieustannie tworzą swoją wiedzę na temat siebie i otaczającej je rzeczywistości, aktywnie konstruując zsubiektywizowane znaczenia. Analizowanie treści znaczeń, jakie dzieci nadają rzeczywistości, umożliwia zrozumienie tego, co myślą, żyjąc w takich, a nie innych warunkach kulturowych i uczestnicząc w kulturowo uwarunkowanych interakcjach społecznych (Klus-Stańska 2004: 15-38).

Zdaniem Kingi Lachowicz-Tabaczek (2004: 95) istnieją cztery podstawowe grupy czynników odpowiedzialnych za tworzenie naiwnych koncepcji rzeczywistości, tj. oddziaływania sytuacji społecznych, kultura, indywidualna aktywność poznawcza jednostki oraz uwarunkowania emocjonalne. Jej zdaniem środowisko społeczne kreowane jest przede wszystkim przez grupy społeczne zawodowe, etniczne, kulturowe, religijne oraz przez rodzinę. Wyróżnione grupy wytwarzają swój system norm, wartości i symboli, na których jest budowany obraz świata. W ten sposób dostarczają one jednostce wiedzy i wskazówek na temat tego, co w świecie jest ważne, czego należy unikać i jak należy definiować obiekty i zdarzenia (Lachowicz-Tabaczek 2004: 96). Dzięki podzielanym społecznie „narzędziom” poznania członkowie grup podobnie definiują konkretne sytuacje i interpretują zdarzenia, budując ,zbiorową świadomość” i tworząc tzw. kulturę komunikowania się. Elementem tej kultury są ukryte teorie pozwalające na przykład przyjąć te same założenia przy odczytywaniu znaczenia pewnych słów czy wyrażeń (Lachowicz-Tabaczek 2004: 96).

Autorka podkreśla fakt, że: „ludzie, wzrastając i uczestnicząc w życiu grup społecznych, uczą się treści i znaczenia kategorii, poprzez które społeczności spostrzegają świat” (Lachowicz-Tabaczek 2004: 96). Co więcej, „Wszystkie elementy środowiska tworzonego 
przez grupy wpływają na jednostkę, ukierunkowując jej działania i sposób konstruowania rzeczywistości. (...) Tak więc sposób konstruowania przez jednostkę rzeczywistości nie jest wiernym odbiciem oddziaływań środowiska kreowanego przez grupy, ale wynikiem odczytania i przyjęcia ukrytych założeń i teorii leżących u podstaw bezpośrednich wpływów grupy" (Lachowicz-Tabaczek 2004: 97).

\section{Dobór uczestników badania i ich charakterystyka}

Opisywane badania zostały przeprowadzone z udziałem 52 trzecioklasistów (22 dziewczynki, 30 chłopców) w wieku 8-9 lat, uczęszczających do publicznej szkoły podstawowej na Śląsku Cieszyńskim. Wybór tej grupy wiekowej opiera się na przesłankach pochodzących: z polskich badań, z których wynika, że około $90 \%$ dzieci z szeroko pojętej normy w wieku ośmiu lat osiąga poziom operacyjny rozumienia wartości pieniądza w zakresie: siły nabywczej w systemie monetarnym, stałej wartości w systemie monetarnym i rozmieniania pieniędzy (Kupisiewicz 2004a: 103, 242, 253), a także z włoskich badań Anny Emilii Berti i Anny Silvi Bombi (1981: 1179-1187; 1988), w których zaobserwowano pełne zrozumienie istoty i funkcji pieniądza u dzieci w wieku 7-8 lat. Warto tutaj przywołać wartościową pracę Janiny Uszyńskiej-Jarmoc (2016: 7-26), która również prowadziła badania $\mathrm{z}$ dziećmi w młodszym wieku szkolnym na temat rozumienia przez nie problemów ekonomicznych świata dorosłych.

Małgorzata Kupisiewicz omawia rozwój dziecięcych kompetencji w zakresie rozumienia stałej wartości pieniądza, umiejętności dokonywania obliczeń pieniężnych oraz rozsądnego gospodarowania pieniędzmi. Rozwój ten autorka wiąże z socjalizacją ekonomiczną, a więc z instrumentalnym postrzeganiem natury pieniądza przez dzieci, pomija natomiast socjalizację $\mathrm{w}$ zakresie reagowania na symboliczną naturę pieniędzy, czyli ich znaczenie psychologiczne czy społeczne. Jak autorka ta twierdzi, dzieci 8-9-letnie potrafią odróżnić pieniądze od innych podobnych przedmiotów, zwracają uwagę na nominały, awers i rewers monet oraz przednią i odwrotną stronę banknotów. Dzieci w tym wieku sprawnie rozpoznają i oddzielają od siebie pieniądze obecnie obowiązujące w transakcjach monetarnych od dawniej używanych monet i nie mają wątpliwości, którymi monetami można obecnie zapłacić w sklepie. Rozpoznawanie i nazywanie nominałów wszystkich monet i banknotów również nie sprawia im trudności. Ponadto dobrze sobie radzą z gradacją pieniędzy, biorą pod uwagę ich rosnącą wartość nominalną, rozmiar pieniądza czy jego kolor zaś nie są dla nich istotne. To, że dobrze znają nominały pieniędzy, sprawia, że nie mają większych problemów z ustaleniem, jakimi monetami można zapłacić w sklepie określoną kwotę. Dzieci w tym wieku są przekonane, że o wartości pieniądza decyduje jego nominał. Ponadto wiedzą, że banknoty mają większe wartości nominalne niż monety, zaś ustalając równowartość pomiędzy banknotem i kilkoma monetami, sumują wartości monet i porównują z wartością banknotu. Dobrze rozumieją, na czym polega rozmienianie pieniędzy i potrafią sprawnie rozmienić monety, banknoty, posługując się różnymi nominałami, choć niektóre dzieci mogą mieć jeszcze z tym problemy. Dość dobrze radzą 
sobie z liczeniem pieniędzy i nie sprawia im większych problemów zliczanie sumy monet o różnych nominałach oraz banknotów i monet, jednak niektóre dzieci mogą mieć jeszcze trudności z podaniem sumy pieniędzy wyrażonej banknotami, monetami złotowymi i groszowymi. Dzieci 8-9-letnie dobrze radzą sobie z odliczaniem właściwej kwoty do zapłaty, sprawnie sumują monety i banknoty o różnych nominałach oraz umieją wydać resztę, gdy dotyczy to małych nominałów pieniędzy, jednak nieco trudności sprawia im jeszcze wydawanie reszty ze $100 \mathrm{zł}$, a także gdy przy wydawaniu reszty muszą się posługiwać monetami złotowymi i groszowymi (Kupisiewicz 2004a: 312-313, 2004b: 36).

W trakcie opisywanych przeze mnie badań z dziećmi wielką wagę przywiązywałam do stworzenia takiej atmosfery podczas podejmowanej przez nie aktywności, by zapewnić im warunki do autentycznego wyrażania tego, co myślą. Poprzedzająca badania rozmowa z dziećmi stała się źródłem informacji, na podstawie których można stwierdzić, że o pieniądzach rozmawiają one przede wszystkim ze swoimi rodzicami (44 osoby), rodzeństwem (24 osoby), dziadkami (20 osób), a także kolegami i koleżankami (17), kuzynkami i kuzynami (12), wujkami i ciociami (9), z opiekunami (1 osoba). Otrzymują pieniądze W różnej formie, ale głównie są to prezenty (32 osoby) lub kieszonkowe (26 osób), a także zapłata za wykonaną pracę (18) i nagroda za bardzo dobre wyniki w nauce (14). Pieniądze, które dzieci dostają od swoich rodziców i krewnych, oszczędzają (48 osób) lub wydają (16). Podane liczby nie sumują się do 52, gdyż dzieci rozmawiają więcej niż z jedną osobą, a także otrzymują pieniądze jednocześnie w różnych formach, niektóre zarówno oszczędzają, jak i wydają pieniądze.

\section{Założenia badawcze, organizacja i przebieg opisywanych badań empirycznych}

Koncepcja przeprowadzonych i opisanych badań z uczniami klas III szkoły podstawowej osadzona została w paradygmacie interpretatywnym. W tym modelu badań słowa są danymi z badań, na których skupia się uwaga badacza. Dzięki wypowiedziom osób badanych, ich narracjom czy tekstom pisanym możliwy jest wgląd w znaczenia nadawane przez informatorów zdarzeniom, w jakich uczestniczą. W tym podejściu istotne są kategorie codzienności i wiedzy potocznej, które pozwalają badaczowi wniknąć w konstrukcje myślowe badanych i ,zrozumieć” sposoby, w jakie nadają oni sens swemu codziennemu życiu (Zwiernik 2015: 81). Badacz interpretatywny poszukuje wielości znaczeń w celu stworzenia puli możliwych znaczeń po to, aby je wypełnić. Tworzy własny sposób opracowania wyników badań w zależności od celu, do którego zmierzał, uwzględniając przy tym zebrane przez siebie dane (Bauman 2013: 89).

Przyjmuję za konstruktywistami, że człowiek nie odzwierciedla poznawanej rzeczywistości w umyśle, ale konstruuje jej obraz, a to, co wie o rzeczywistości, jest zbiorem znaczeń, jakie nadaje światu. W ten sposób człowiek konstruuje obraz świata, uzgadniając go tak, by możliwe było skuteczne w nim działanie (Klus-Stańska 2018: 132, 135). Konstruktywizm to teoria, w której podważono tezę, że człowiek pobiera i przejmuje przekazywaną 
wiedzę. Zakłada się w nim, że w procesach poznawczych umysłowy obraz świata zawsze jest konstruowany, gdyż natura procesów poznawczych jest konstruktywistyczna. Ponadindywidualny mechanizm nadawania znaczeń jest eksponowany w konstrukcjonizmie społecznym, w którym podkreśla się, że wiedza jednostki nie jest izolowana, ale współtworzona w procesach negocjowania znaczeń. Jego przedstawiciele koncentrują swoją uwagę na zjawiskach związanych: z językiem, komunikacją, relacjami konwersacyjnymi, które traktują jako podstawę tworzenia obrazu świata (Klus-Stańska 2018: 134-136). Zgodnie z paradygmatem konstruktywizmu społecznego rozwój podmiotowy dziecka postrzegany jest jako część szerszego kontekstu (społecznego, kulturowego i ekonomicznego), który jest społecznie tworzony i modyfikowany, a dziecko, uczestnicząc w tym procesie, rozwija swoje kompetencje do podmiotowej adaptacji (Bałachowicz 2015: 184).

W nowym myśleniu o edukacji w młodszym wieku szkolnym uwzględnia się w procesie kształcenia aktywną postawę ucznia w konstruowaniu wiedzy, jego wiedzę osobistą i pozaszkolne doświadczenia. Warunki, w których wzrasta współczesne dziecko, naruszają stabilność dotychczasowych podstaw rozumienia oddziaływań dydaktycznych jako sformalizowanych i zamkniętych na wiedzę i doświadczenia pozaszkolne dziecka, nabywane w codziennej przestrzeni życia (Kochanowska 2018: 11). Zgodnie z konstruktywizmem, uzupełnionym o najnowszą teorię uczenia się, zwaną konektywizmem (Uszyńska-Jarmoc 2013: 42), dzieci we właściwy sobie sposób budują własne, potoczne, naiwne koncepcje na temat świata, gromadząc, porządkując, modyfikując czy uogólniając różnorodne doświadczenia (poznawcze, społeczne i praktyczne) w sytuacjach zaplanowanych i/lub niezaplanowanych, (przed)szkolnych lub poza(przed)szkolnych - w bezpośrednich interakcjach poznawczych bądź społecznych albo w pośrednich, to jest w sieci (społecznej i informatycznej) i organizacji (Uszyńska-Jarmoc 2013: 42, 45, 47). Te koncepcje świata ekonomii (w tym pieniądza) tworzone przez dzieci w trakcie początkowych lat ich życia powinny być docenione i wykorzystane w edukacji wczesnoszkolnej. Wiedza osobista każdego dziecka stanowi „preludium” do zdobywania wiedzy naukowej na temat pieniądza i jego uwikłań w społeczno-kulturowej rzeczywistości, w której żyje.

We wspomnianej teorii uczenia się - konektywizmie - przyjmuje się, że technologia modyfikuje umysły, a narzędzia, których ludzie używają, kształtują ich myślenie. Organizacja i jednostka są równouprawnionymi uczącymi się organizmami. Dla konektywizmu punktem wyjścia jest jednostka, choć uznaje się, że jej osobista wiedza jest pozyskiwana z sieci (społecznej i informatycznej), a także dostarczana do nich. Informacje istniejące w sieci informatycznej zasilają organizacje, które je przetwarzają i uzupełniają, a w rezultacie nowe wzbogacone informacje wracają do sieci. Pozwala to uczącym się na dostęp do bieżących informacji dotyczących interesującego ich tematu. Jest to możliwe dzięki połączeniom, które sami stworzyli (Uszyńska-Jarmoc 2013: 42).

Celem opisywanych w artykule badań empirycznych przeprowadzonych z udziałem dzieci było zbadanie uogólnionej dziecięcej wiedzy potocznej na temat pieniędzy. Zmierzałam do analizy treści ,gotowych” znaczeń pieniądza, wyrażonych przez dzieci w formie pisemnej. Pytania badawcze sformułowałam następująco: Jakie są potoczne przeko- 
nania 8-9-letnich dzieci na temat pieniądza? Czy wśród ,gotowych” znaczeń pieniądza, wyrażonych pisemnie przez dzieci, można dostrzec takie, które odnoszą się do instrumentalnej i symbolicznej natury pieniądza?

Źródłem pozyskania znaczeń odnoszących się do pieniędzy stały się pisemne wypowiedzi dzieci. Zestaw 12 niedokończonych zdań dotyczących pieniędzy to autorskie narzędzie, które posłużyło do ich zebrania. We wspomnianym narzędziu badawczym zdania te rozpoczynają się na przykład od słów: „Pieniądze to...”, „Dzięki pieniądzom...”, „Bez pieniędzy...”, ,Zamiast pieniędzy...”, ,Z powodu pieniędzy...”. Są to początkowe słowa zdań, które uzupełniały dzieci. Wypowiedzi uczniów przytoczono w dalszej części artykułu. Warto zwrócić uwagę na to, że w niedokończonych zdaniach zostało użyte słowo „pieniądze”, a nie „pieniądz”, gdyż jest ono bliższe dzieciom. Narzędzie zastosowane w badaniach traktuję jako swoistą matrycę pomocną w zorientowaniu się w tym, jakie jest potoczne, zdroworozsądkowe spojrzenie dzieci na pieniądze. Pisemne wypowiedzi dzieci były zbierane z zamiarem poddania ich $\mathrm{w}$ dalszej kolejności analizie naukowej.

W prowadzonych badaniach wzięłam pod uwagę to, że: ,niezwykle ważną cechą badacza dzieciństwa jest umiejętność jasnego zakomunikowania dzieciom, na czym polega badanie, co interesuje badacza, jaka jest jego rola, jakie są oczekiwania wobec dzieci i upewnienie się, czy chcą w nich uczestniczyć" (Zwiernik 2015: 86). W związku z tym zadbałam o to, aby pisemną instrukcję rozszerzyć o wstępną rozmowę, poprzedzającą aktywność dzieci. Rozmowa ta miała na celu przedstawienie moich intencji jako badacza oraz otrzymanie aprobaty ze strony dzieci do udziału w badaniach. Na etapie gromadzenia danych, tj. w trakcie procesu uzupełniania zdań, a także w fazie poprzedzającej ten etap, zadbałam o stworzenie sprzyjającej atmosfery. Uczniowie zostali zapewnieni o tym, że ich pisemne wypowiedzi nie będą oceniane, co przyczyniło się do swobodnego wyrażania pomysłów. Ponadto upewniłam dzieci, że nie ma dobrych i złych odpowiedzi, dając im możliwość pełnej swobody w uzupełnianiu niedokończonych zdań. Opisane zabiegi pozwoliły na zbudowanie wzajemnego zaufania, co znalazło potwierdzenie w trakcie rozmowy z dziećmi kończącej badania. Był to czas „żywej wymiany” zdań, ujawniających ich zainteresowanie tematem pieniędzy.

\section{Wyniki badań, ich analiza i interpretacja}

W omawianym projekcie badawczym zastosowałam jakościową analizę danych, którymi są ,gotowe" znaczenia pieniądza zakomunikowane pisemnie przez dzieci. Źródeł tych znaczeń nie sposób zidentyfikować ze względu na zaplanowaną procedurę badań, tj. pisemne uzupełnianie niepełnych zdań. Jednak z przedstawionej charakterystyki badanych dzieci można wnioskować, że są nimi m.in. osoby, z którymi dzieci rozmawiają o pieniądzach (członkowie najbliższej rodziny, zarówno dorośli, jak i dzieci). Wspomniane znaczenia można traktować jako przekonania potoczne, przejęte od dorosłych, będące efektem procesu pierwotnej socjalizacji ekonomicznej, przebiegającej w obrębie najbliższej rodziny we wczesnym dzieciństwie. Potoczne przekonania o rzeczywistości określa 
się różnymi terminami, np. zdroworozsądkowe sądy, ukryte przekonania, intuicyjne przekonania, naiwne teorie, naiwne koncepcje (Lachowicz-Tabaczek 2004: 70).

Moje zadanie jako badacza polegało na odkryciu przekonań dzieci 8-9-letnich na temat pojęcia „pieniądz”. Analiza pisemnych wypowiedzi trzecioklasistów rozpoczęła się od wielokrotnego ich odczytania, co wiązało się z zapoznawaniem się z dwunastoma zdaniami uzupełnionymi indywidualnie przez każde dziecko. W dalszej kolejności zdania uczniów były porównywane ze sobą i grupowane ze względu na różne aspekty ujmowania pojęcia „pieniądz”. W trakcie analizy treści znaczeń, zgodnie z wcześniej zasygnalizowaną dwoistością natury pieniądza, wśród wyrażeń opisujących to pojęcie dostrzegłam takie, które można byłoby odnieść zarówno do jego instrumentalnej, jak i do symbolicznej natury. Część pisemnych wypowiedzi dzieci koncentruje się wokół instrumentalnej natury pieniądza, czyli dotyczy jego wartości użytkowej i funkcji ekonomicznych, inne zaś mają charakter pozaekonomiczny i łączą się z symboliczną naturą pieniędzy, tj. z ich psychologicznym i społecznym znaczeniem. W pierwszej grupie wypowiedzi znalazły się te, które opisują pieniądz jako:

- środek płatniczy (wymiany), dzięki któremu możemy kupować dobra i usługi:

Pieniądze to monety i banknoty; Pieniądze to coś, co wymyślił człowiek; Pieniądze to papier i metal; Pieniądze to papier z napisem i obrazkiem; Pieniądz to rzecz do płacenia; Oprócz pieniędzy można płacić kartą; Dzięki pieniądzom możemy żyć i kupować rzeczy potrzebne do życia; Pieniądze są potrzebne do życia, żeby mieć ubrania, jedzenie i dom; Pieniądze są potrzebne, by płacić prąd, gaz i wodę; Pieniądze są potrzebne do [kupowania - R.R.] syropów, antybiotyków, tabletek; Pieniądze to bardzo drogocenne rzeczy; Z powodu pieniędzy możemy kupić coś, o czym marzymy; Dzięki pieniądzom możemy kupić wiele rzeczy, ale nie wszystko; Z pieniędzmi jest się bardzo bogatym i niczego nie brakuje;

- środek akumulacji:

Pieniądze powinno się oszczędzać;

- zapłata za pracę:

Pieniądze to zarobki; Pieniądze to rzeczy, które zbierasz za pracę np. w sklepie; Dzięki pieniądzom nasz wysiłek się opłaca;

- środek rozwoju lub kryzysu gospodarczego:

Z powodu pieniędzy powstają fabryki; $Z$ powodu pieniędzy są domy i miasta; Z pieniędzmi można osiągać cele; $W$ pieniądzach rosną długi; $Z$ powodu pieniędzy można wiele stracić; $\mathrm{Z}$ powodu pieniędzy ludzie bankrutują; 
- środek, którym trzeba właściwie zarządzać:

$\mathrm{Z}$ powodu pieniędzy często ludzie mają problemy rodzinne lub finansowe; $\mathrm{Z}$ powodu pieniędzy można zniszczyć sobie życie; Pieniądze są niebezpieczne; Z pieniędzmi nie ma żartów; $\mathrm{O}$ pieniądze trzeba dbać; $\mathrm{Z}$ pieniędzmi musimy się obchodzić powoli; W pieniądzach jest zło i dobro; Pieniądze są złe, jeśli używa się ich niemądrze; W pieniądzach można się kąpać;

- pieniądze jako środek potrzebny lub niepotrzebny w życiu codziennym:

Pieniądze to banknoty i monety, które pomagają w życiu; Z pieniędzmi można ułatwić sobie życie; Pieniądze są przydatne; Pieniądze są potrzebne, ale często niebezpieczne; Pieniądze są bardzo ważne, ponieważ potrzebne są do życia; Pieniądze to zła rzecz, ale czasami potrzebna; Pieniądze są niepotrzebną rzeczą w życiu dziecka.

Wypowiedzi, które znalazły się w drugiej grupie, można dodatkowo podzielić na odwołujące się do emocji związanych z pieniędzmi oraz ich funkcji społecznych. Pieniądze są postrzegane przez dzieci jako źródło emocji:

- pozytywnych:

Z powodu pieniędzy można się cieszyć; $Z$ pieniędzmi jest dobrze; $Z$ pieniędzmi czuję się lepiej, bo wiem, że mam jedzenie;

- negatywnych:

Z powodu pieniędzy czasami się złoszczę;

- skrajnych:

Z powodu pieniędzy czuję radość i trochę złości.

W społecznym wymiarze percepcji pieniądza mieszczą się te wypowiedzi uczniów, które traktują pieniądze jako:

- temat rozmów:

O pieniądzach można rozmawiać; O pieniądzach można dyskutować; O pieniądzach niektórzy mówią dobrze, a inni źle; O pieniądzach nie mówimy brzydkich rzeczy; O pieniądzach jest dużo mówione na całym świecie; O pieniądzach się nie rozmawia;

- środek umożliwiający niesienie pomocy innym:

Z pieniędzmi można się dzielić; Z powodu pieniędzy można kupić leki dla chorego; Dzięki pieniądzom powstają ośrodki, hospicja; Pieniądze są, by pomagać dzieciom; Pieniądze są ważne na różne cele charytatywne; 
- źródło zepsucia i konfliktów międzyludzkich, międzynarodowych:

Z powodu pieniędzy jest zło; W pieniądzach jest dużo zła; Pieniądze są złe; $Z$ powodu pieniędzy ludzie robią się gorsi; $Z$ powodu pieniędzy ludzie są samolubni; $Z$ powodu pieniędzy niektórzy są uzależnieni; Dzięki pieniądzom czujemy się lepsi, a stajemy się gorsi; Pieniądze są złe, rozdzielają ludzi; Z powodu pieniędzy niektórzy ludzie nie mają przyjaciół; $\mathrm{Z}$ powodu pieniędzy są wojny; Z powodu pieniędzy są konflikty na świecie;

- wartość wśród innych wartości, o które zabiegamy w życiu:

Pieniądze to wielka wartość; Oprócz pieniędzy jest szczęście, którego nie kupisz; Pieniądze nie dają szczęścia; Oprócz pieniędzy kocha się ludzi; Oprócz pieniędzy w życiu ważna jest rodzina; Oprócz pieniędzy liczy się życie i zdrowie; Pieniądze nie są cenniejsze od miłości; Pieniądze są nam potrzebne do życia, ale nie są najważniejsze; Pieniądze to nie najważniejsza rzecz; Z powodu pieniędzy można być nieszczęśliwym; W pieniądzach niektórzy widzą wszystko, ale nie ja; Pieniądze są dobrem od Pana Boga;

- środek roznoszenia chorób:

Pieniądze to choroby; W pieniądzach są zawarte różne zarazki; W pieniądzach są bakterie.

\section{Wnioski}

Opisane efekty jakościowej analizy danych pozwalają na przedstawienie podzielanych, potocznych przekonań dzieci w młodszym wieku szkolnym na temat pojęcia ,pieniądz”. Instrumentalna i symboliczna natura pieniądza manifestuje się $\mathrm{w}$ wyrażonych pisemnie wypowiedziach trzecioklasistów. Dzieci w tym wieku są w stanie wskazać wiele cech i funkcji pieniądza, odwołują się do jego historii, dostrzegają jego pozytywne zastosowania w życiu codziennym (wynik pracy, czynnik rozwoju, możliwość niesienia pomocy osobom w potrzebie), wyczuwają również zagrożenia związane z niewłaściwym podejściem do pieniądza (uzależnienia, konflikty). Słowem, dzieci w młodszym wieku szkolnym znają mocne i słabe strony pieniądza, wiążące się z nim możliwości oraz zagrożenia, co powoduje powstawanie napięć związanych z codzienną koniecznością dokonywania trudnych wyborów, radzenia sobie z wahaniami i rozterkami.

Moje początkowe poszukiwania badawcze były ukierunkowane na poznanie postrzegania instrumentalnej natury pieniądza przez dzieci. Jednak na podstawie wyników analizy materiału badawczego można uznać, że nie można pomijać dwoistości charakteru pieniądza. Wśród wyrażeń, jakimi dzieci kończyły niepełne zdania, pojawiły się nie tylko te odnoszące się do instrumentalnej natury pieniądza, ale również do znaczeń psychologicznych i społecznych, łączących się z jego symboliczną naturą.

Słabością badań przeprowadzonych techniką niedokończonych zdań jest to, że dają one pewien obraz rozumienia przez dzieci pojęcia ,pieniądz”, ale jest on niepełny, niedo- 
powiedziany. By uczynić go kompletnym, należałoby przeprowadzić rozmowę z każdym dzieckiem, aby móc wyjaśnić rodzące się wątpliwości, pytania i uzupełnić o niewyrażone pisemnie przekonania każdego dziecka.

Przedstawiony sposób gromadzenia i analizy pisemnych wypowiedzi uczniów może się stać inspiracją dla nauczycieli edukacji wczesnoszkolnej do podejmowania tematu pieniądza w trakcie zajęć edukacyjnych, a także dla rodziców i opiekunów dzieci w młodszym wieku szkolnym. W ten sposób nauczyciel, wychowawca czy rodzic mogą poznać potoczne przekonania dzieci na temat pieniędzy i zainicjować rozmowę na ich temat. Niedokończone zdania (zaproponowane lub inne) mogą być uzupełniane w trakcie rozmowy dorosłych z dziećmi zgodnie z metodą burzy mózgów (m.in. giełda pomysłów należy do grupy metod gier dydaktycznych) lub tworzenia map myśli (przykład mnemotechniki) indywidualnie lub w grupach. Ostatecznie pomysły dzieci mogą zostać wspólnie ocenione lub stać się przedmiotem dyskusji. Różnorodność przekonań, opinii, wiedzy potocznej dzieci, pochodzących z przekazu społecznego, może się stać tematem rozmów inspirujących do negocjowania znaczeń pieniądza, wspólnego odkrywania, porządkowania oraz konstruowania naukowych pojęć związanych ze światem ekonomii. Treść wypowiedzi pisemnych lub dopowiedzeń ustnych może dać początek rozmowom wychowawczym, które są bardzo potrzebne. Jak zauważa Rutkowiak (2012: 38), współczesna „spieniężona” rzeczywistość dostarcza poważnego tematu do rozmów wychowawczych.

\section{Literatura}

Bałachowicz J. (2015), Nauczycielski dyskurs a konstruowanie podmiotowości dziecka. W: J. Bałachowicz, A. Witkowska-Tomaszewska (red.), Edukacja wczesnoszkolna $w$ dyskursie podmiotowości. Studium teoretyczno-empiryczne. Warszawa, Wydawnictwo Akademii Pedagogiki Specjalnej.

Bauman T. (2013), Kompetencje badawcze a świadomość metodologiczna. W: T. Bauman (red.), Praktyka badań pedagogicznych. Kraków, Oficyna Wydawnicza „Impuls”.

Belk R.W., Wallendorf M. (1990), The sacred meaning of money. „Journal of Economic Psychology", 11.

Berti A.E., Bombi A.S. (1981), The development of the awareness of money and its value: A longitudinal study. „Child Development”, 52.

Berti A.E., Bombi A.S. (1988), The child's construction of economics. Cambridge, Cambridge University Press.

Furnham A., Argyle M. (2000), The psychology of money. London-New York, Routledge.

Gąsiorowska A. (2013), Skrócona wersja Skali postaw wobec pieniędzy (SPP-25). Dobór pozycji i walidacja narzędzia. T. 8. „Psychologia Społeczna”, 4(27).

Gąsiorowska A. (2014), Psychologiczne znaczenie pieniędzy. Dlaczego pieniądze wywohuja koncentrację na sobie? Warszawa, Wydawnictwo Naukowe PWN.

Gąsiorowska A., Zaleśkiewicz T., Wygrab S. (2012), Would you do something for me? The effects of money activation on social behaviour and social preferences in young children. „Journal of Economic Psychology", 33(3). 
Klus-Stańska D. (2004), Światy dziecięcych znaczeń - poszukiwanie kontekstów teoretycznych.

W: D. Klus-Stańska (red.), Światy dziecięcych znaczeń. Warszawa, Wydawnictwo Akademickie ,Żak”.

Klus-Stańska D. (2018), Paradygmaty dydaktyki. Myśleć teoria o praktyce. Warszawa, Wydawnictwo Naukowe PWN.

Kochanowska E. (2018), Wiedza osobista dziecka w refleksji i praktyce nauczycieli edukacji wczesnoszkolnej. Kraków, Oficyna Wydawnicza „Impuls”.

Kupisiewicz M. (2004a), Edukacja ekonomiczna dzieci. Z badań nad rozumieniem wartości pieniadza i obliczeniami pieniężnymi. Warszawa, Wydawnictwo APS im. M. Grzegorzewskiej.

Kupisiewicz M. (2004b), Jak kształtuje się u dzieci rozumienie wartości pieniądza. Warszawa, Wydawnictwo APS im. M. Grzegorzewskiej.

Lachowicz-Tabaczek K. (2004), Potoczne koncepcje świata i natury ludzkiej. Ich wptyw na poznanie i zachowanie. Gdańsk, Gdańskie Wydawnictwo Psychologiczne.

Lea S.E.G., Webley P. (2006), Money as tool, money as drug: The biological psychology of a strong incentive. „Behavioral and Brain Sciences”, 29.

Mishkin F.S. (2002), Ekonomika pieniądza, bankowości i rynków finansowych. Warszawa, Wydawnictwo Naukowe PWN.

Rutkowiak J. (2012), Pieniadze a oddziaływania wychowawcze $w$ warunkach rzeczywistości neoliberalnej. W: J. Rutkowiak, D. Wajsprych (red.), Między negacja a afirmacja - czy kryzys oddziaływań pedagogicznych? Kraków, Oficyna Wydawnicza „Impuls”.

Uszyńska-Jarmoc J. (2013), Uczenie się dzieci jako warunek ich rozwoju i nabywania kompetencji kluczowych. W: J. Uszyńska-Jarmoc, B. Dudel, M. Głoskowska-Sołdatow (red.), Rozwijanie kompetencji kluczowych uczniów w procesie edukacji wczesnoszkolnej. Kraków, Oficyna Wydawnicza „Impuls”.

Uszyńska-Jarmoc J. (2016), Uczenie się a zarobki - dziecięce rozumienie problemów ekonomicznych świata dorostych. „Problemy Wczesnej Edukacji”, 1(32).

Wąsowicz-Kiryło G. (2008), Psychologia finansowa. O pieniądzach w życiu człowieka. Warszawa, Wydawnictwo Difin.

Zaleśkiewicz T. (2011), Psychologia ekonomiczna. Warszawa, Wydawnictwo Naukowe PWN.

Zaleśkiewicz T. (2012), Symboliczna natura pieniędzy: ujęcie psychologiczne. „Chowanna”, tom specjalny.

Zwiernik J. (2015), Podejścia badawcze w poznawaniu wiedzy dziecka. W: J. Uszyńska-Jarmoc, M. Bilewicz (red.), Kompetencje kluczowe dzieci i młodzieży. Teoria i badania. Warszawa, Wydawnictwo Akademickie „Żak”, Fundacja Centrum Transferu Wiedzy i Innowacji Społeczno-Pedagogicznych. 